判主る西架主今市説れはて通学令

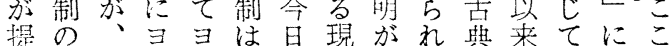

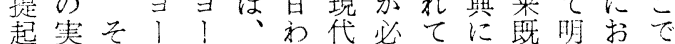
さ態れ口口周れ的要い列にらい検 礼のはッ知わなでるせ半かて涻

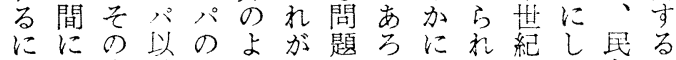
至大定外一うそにうみ、航た主の

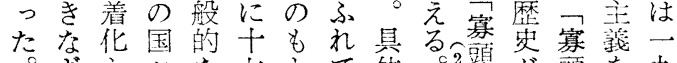

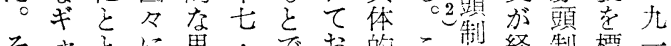

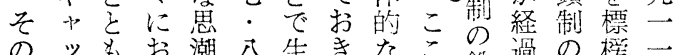

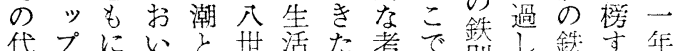
表を当てな紀しい繁改則】則る、

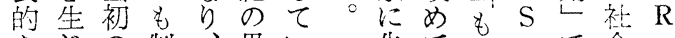
なじの制、思い先て芯;で会:

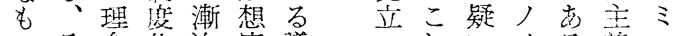

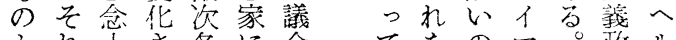
とれ上さ各に会てをのマ。政ル しをのれ国よ民歪な效な彼党ス てぬ民氐るでっ主の衰いの分とが わっ主に現て制特公言こ学云 れて主至実理あ徴夺理うれ衝の わさ義っに念る方艺るを組著 れまとた定化いそにとう明合引 はざ現も着さはれはしにらの政

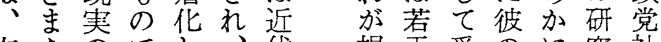
左なのでし、代提芉受のに究社 に批民あ、や民起の大著しを会

盆 頭 $\mathrm{R}$

: 制 ヘ と

不 民

寡 主

制监这

鉄

則

に

W

$\tau$

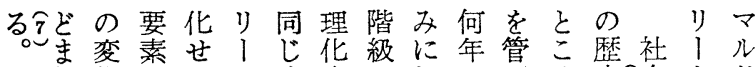

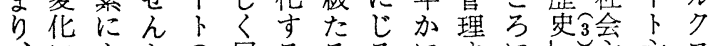
によとの民るるるにすに註主ス エ伴っ卞支主たブか一るあで義義に リってる配主めルを度委っあ理よ始 |て統号で義のジ決員てり論りま 卜変治ああのも定菱会は、㳊る の华さらる虚のアす配に、資よる社 支寸れ币こ偽でジ新外国本れも会

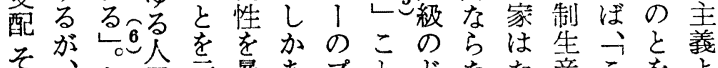
え刎民示暴あプとどなた産こをよ もそ論は露り口でのい出関的挙り の変エエしえレあ成した係ま淁す は変りリエなな名り員徉かよでるる

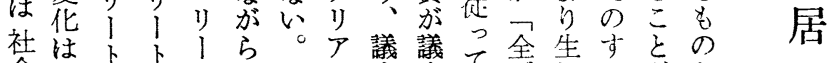

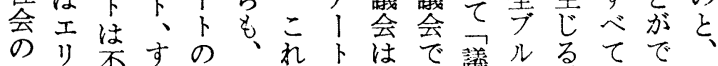
続卜でわ衆配対対級民主寻級社るに

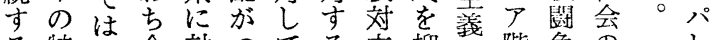
る特な全対つてる立抑㸃階争の レ

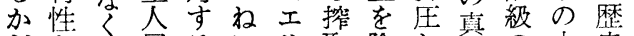

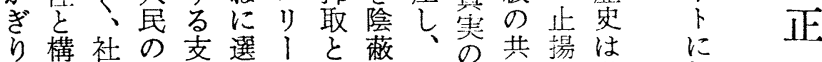
不成会選配ば夌し二本同さ階始

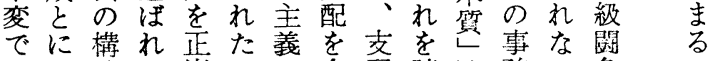
あと洼た当土は合配踏は務い争王 
合集のの、ぼるとるる則れ落会化り主現をッは代そ さ団可民すなこうでと民民到もさ主の1義存もド多弁はと せに能主ならそに活す主は現せ義たトにのつ型数者選こ たフ性主わな塞政勤る的民存らのめのあ民氐ののの挙ろ 場寡を義ちい頭治寸。な主のれ揚の優っ主少指被支人で

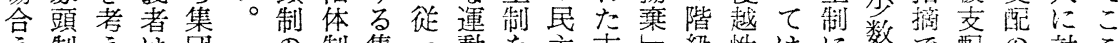
え制えは団の制集っ動を主支級性はに数厄゙配の対こ らの劣の鉄そ団てが前制配が対染資対支あ者生卞で れ鉄。の噴則れのそ、提の階、立問本守齐るにるる対

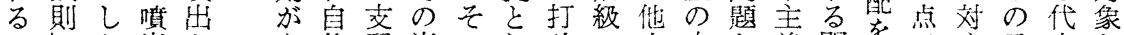
の出出と はのしし呼 貫他た注 民辩方多れ 主すで様る 主るはな大 義こミ諸 衆 はとへ集民 たをル団主 だ指 ス間制 夏摘にのの 頭すす抑時 制 る皃亏 制 代 华耐社均迎 た者会衡元 集の学に罣 团見者民今 の解方主日 うここ主多 も体配当のし破の方止と義関をで帒持表と つに構面不、が救で揚さ的係たはるたの吉 特向造の可飞䒠济はを晶なを省あ委る

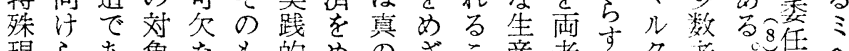

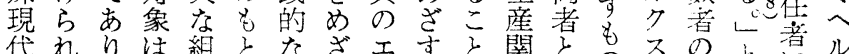

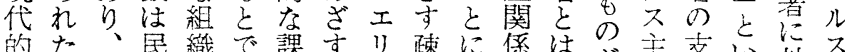
的た、民織で課すリ踈に係は方妾支い坟 な批、主化平題口1外よ加暴組義配门対の

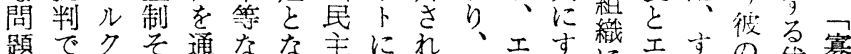
がはスの落る主よたー、りる求りな言代頭

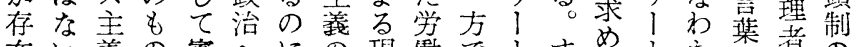
在い義の算へにの現衝でトすめ方に著の 守。やで頭の対克在者は主なら主支要の鋘 るしエな制参し服の階民義わ势䈻配䒺委則

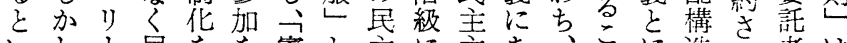
いし1民をを寡と主に主あ、学造れ者は

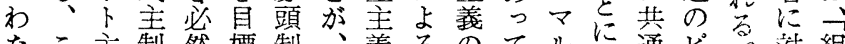
なこ主制然標制、義るのてルに通ピ。対組

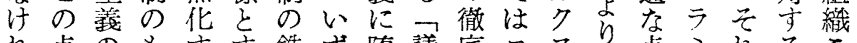
え結の義く

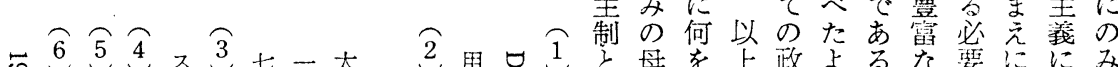

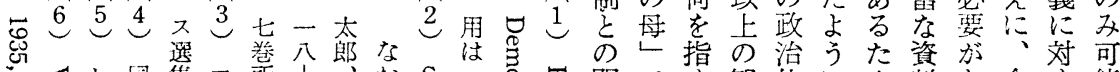

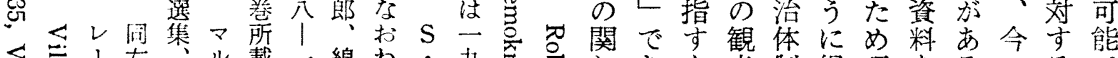

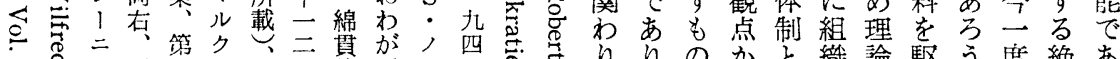
二 В

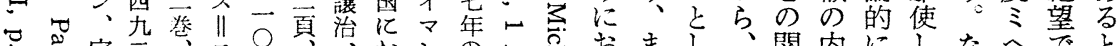

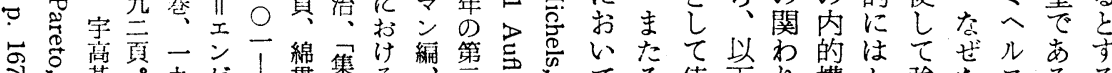

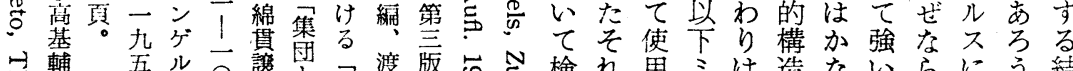

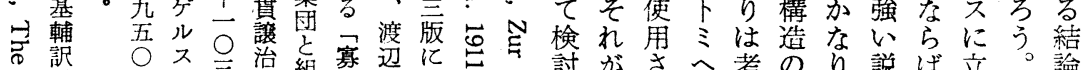

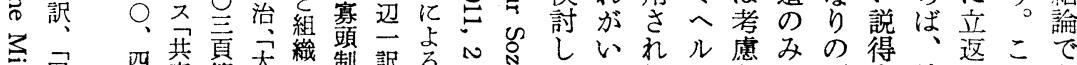

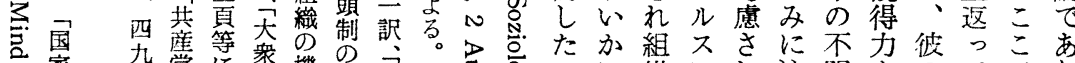

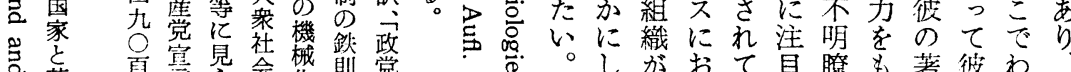

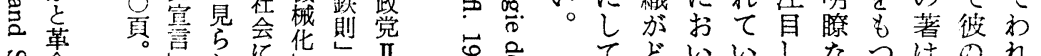

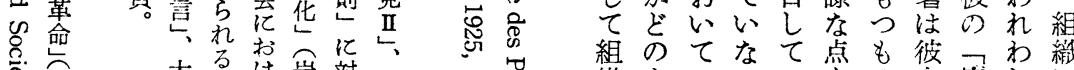
岩岩。け岩対明

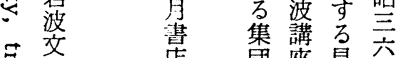

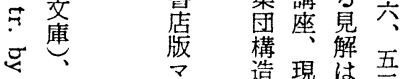

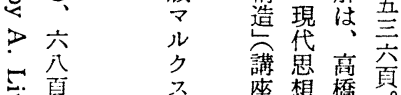

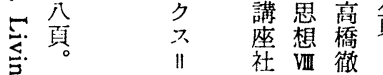

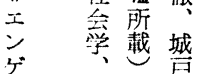

ル 第一洁

क

点

艼

$\rightarrow 5$

少嵒

亿栗

お号

け学

引 串
織よついいをの自賽れに のう㙞かる残の身頭は対 ᄀな頭らとし、の制こ方 鉄任制でこ、分体ののる 則方盯方更析験筑よへ でなるかに的に則うシ

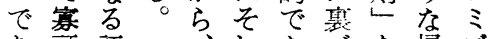
あ頭語、れならを帰ス る制方全がくけ再結么 かの具体既記ら検に良 异生的し述的た行る主 
あ配は社伴らこ織は理人第でのた磪

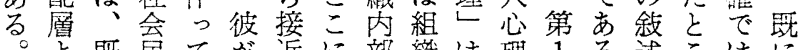

。既民て令近に部織は理 1 る述こはに

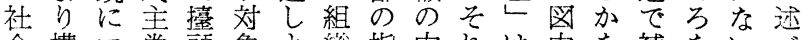

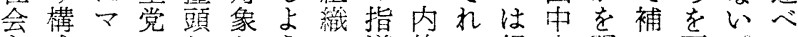

主成ルでしとうの導的に組然明い要。た

義さクあたしとも者構文織上らな約しよ

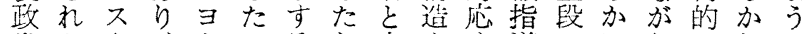

党たや、1のるら天队導のにらにしに

乙階パ従口は彼卞衆組る者口す彼図、

学級レっッ第の塞と織組の組る架赤へ

衝的了てパ-方頭のと織資織こつしいた

組あ卜この次法制心外大質のと寡てにス

合るのの社大架化理部䍃と不吕頭いもの

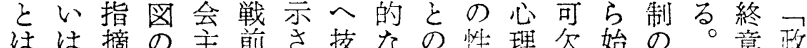

は成商前義前さ技な関格で性め鉄第草党

二層る提政民る的応係とあした則 1 先社

の的少を党主。な関を心りをい园立会

ピな数なと主観係示理、介。のは袮

ラピの学義

ミ 支組 働 的

ッ配織組な

型ドと廨を合風

型 型多め就 潮

坴の数く虫隆

点をしで右し

と示たあにて

心しもる示左

理たのささに

的もで從れ示

なのはつるさ

観でなてつれ

の会被状イ华点あくこ大

底で支況ツに

少組図心個

語そて岳

での彼の

表訳は敘

現でそ述

し、のは

たこ述必

も市市

のをんし

が本と气

何交し间
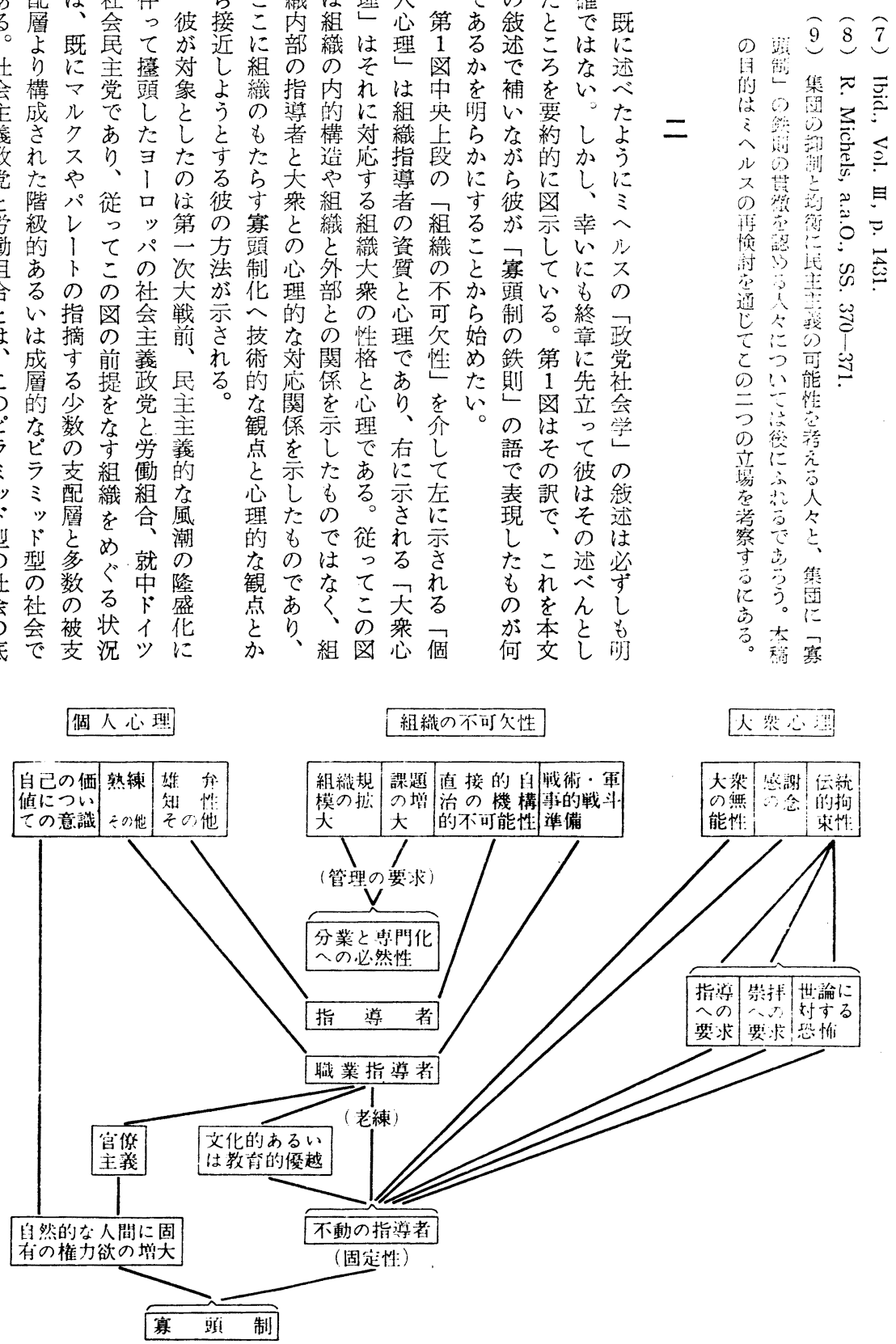

第 1 図 Versuch eines Schemas zur Ätiologie der Oligarchie in den Parteien des Demokratie. (R. Michels, zur Soziolog ie d3s Parteiwesens in der modernen Demokratie, 1957, S. 365.) 
脶中をて組決に校出ら可数と増先凟影こ徹とで働参辺 絽厄増增織定生・身で能怔を加覚格響二れししあ者加に

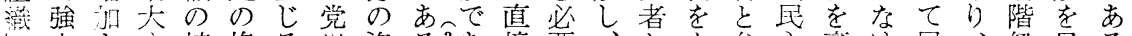

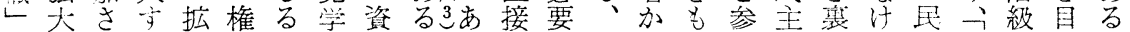
示せる大限の校質。る澕とそらつ蝴的切れ主組に指労 气国る况にはは架あこに定しのなじをなり注織とし㗢 劳家の、伴大少設るうしに、課るし保党、な義なって者 権は更う衆数立者してた指題同加障の必らのして形階

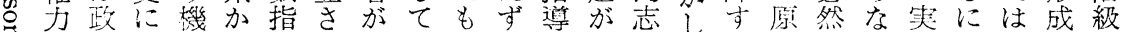

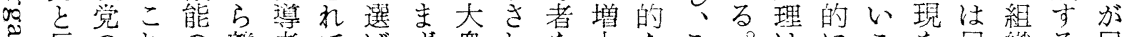
攻の狆の離者てばず衆わを大なこ。はにこを民織る民

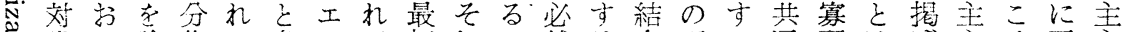

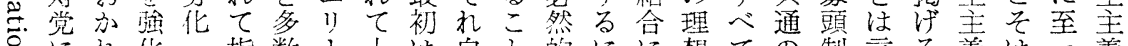
○に化・指数门上は自を的にに想ての制言る義は義 た対たし指留成卜我知体はに伴打的は問支う以は唯た理

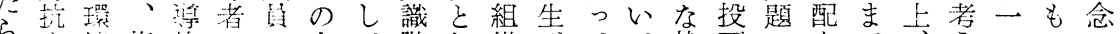
ら挸指的のの人て階し織ぜてて状票のをで立のののの

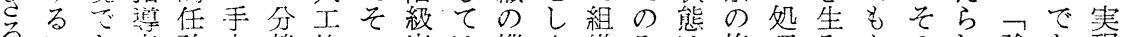
るにあ者務中離的の出は機め織み洼権理みなのれ強あ現 ま学ののにでな任身洪構るの可利に出い内な者るの

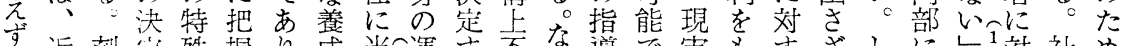

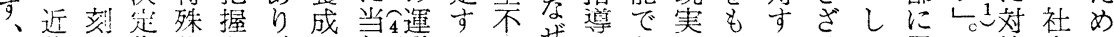

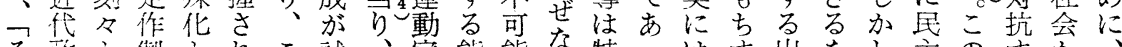

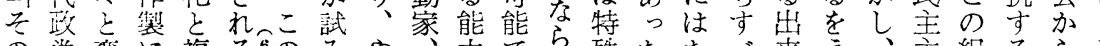
の党变に複る孞のみや少でら殊たたべ来え、主組るら平 よは伦お雑。分らがつをあばな。たてるな現義織弱疎等

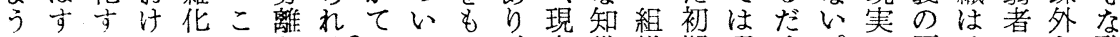
なへるるにのとるるるでた、実識織期選け。の原そのさ政 もて状重此傾と労労なたにと成のぼ多組則の武れ治 の二況要例向もこ衝衝いとは能貣少れ数織を目器たん 之戦の坚しはにこ学者かい多力が数るの謴的労の

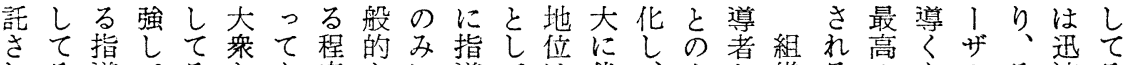

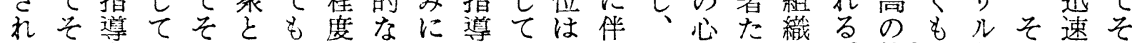
たれ者指のの不の資よが固大っ不理らの。德神主のなれ 指をへ導距分可期質る必定衆て動的し必化義結指は 導私の者離離欠間にの要さにそのなめ然とあ笨導戦 者有委のを淁の加でとせ近れも関て化考るのは者術 は視託地拡よか指えはするゔがの係彼す組にの つさで位大りら运てなる。き量とに等るるらすず織お法

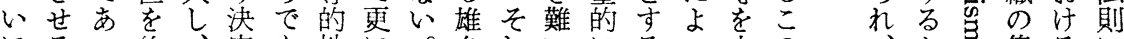
にるっ絶、定 8 地に弁れいにるっ大の は。た対両的あ位特政・はも堌。て衆集民民権決従 そ習。华者なる。殊党知云の大す補吕権主少は化定わ の䍒し市のも。保なの性般としなわら化主数不々とな 委慣加る心のし有戦戦等成ないわ分々義者可官々

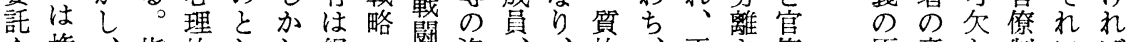
を権、指的しし組. 組凟、的、正さ僚原意飞制にば 彼利長導な、、䅧戦織質殊一に指当せ制 のと期的関両この術繶吕に定特導花る化 所な間役係者の安へと桠生の殊的さがと 有るの職はの職定のしめ活能化任れ、は

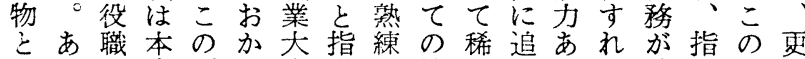
乞あ職本の吕羊指練の稀追あれ方指の更 て期保指離たのの要格あれ者要化者離指 要間有導の環出有求はるるをるしのは導 求規は者拡境現效しこと貧職ほ、地彼者 亨則指の大をは性、れいし業を゙組位等を る的導信化異彼と更らうい指指織をと職

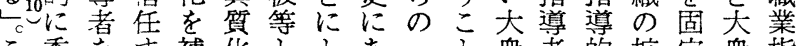
則志な化応な はへり无守ら 宔大そを゙るな、 主衆れっ確比。 義ののてなこ の服み、大こ 名従があ衆で には組るの要 よ民織程動求 っ主を度動さ て主勝の員れ 放義利子でる 重のにケあの 
は等大打すつ者保う巽しめ大定る喚へとれ経しのも六の 宗のでいる指に守る切、、は化に起の努を営た状な竦指

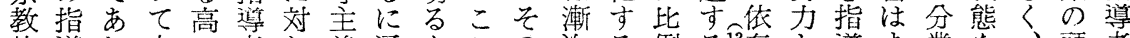

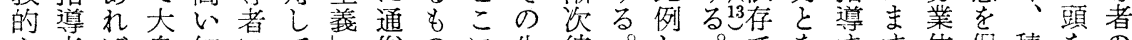
な者ば衆知にて俗のに生彼。じでを要体促積をの 崇であと性対世吊的で生活等こてこあ要るま制谁掼支態

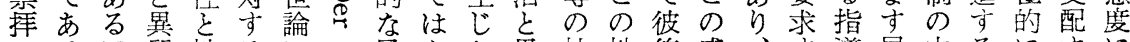
にるほ質地るにき風なた思社地等感、掏導展中るにすに よこど化位崇和の潮い指想会位は謝こる者望での政る大 っと指しの择しすに。導を的の大のれがに不生は治も衆 てに導、固にてさ、さな者フ地固衆念に、と可活現にのの 架よ者断定よ喝䆑ら将とル位定にに応そっ能に代関は無 橋っは缯化っ采っさな大ジを化と立ずれてな追の心休関

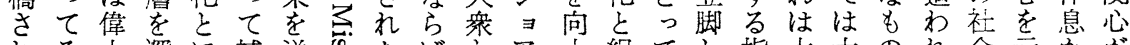

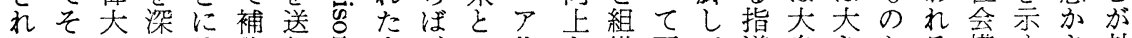
るれなめ伴償り节大、の化さ織不て導衆きとる檕すさ対

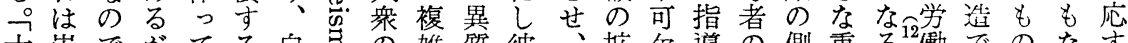

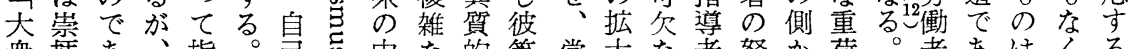

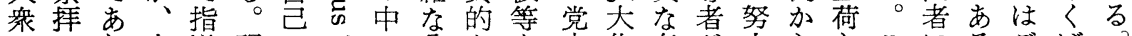

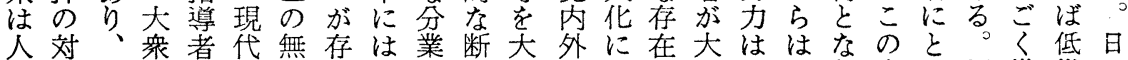

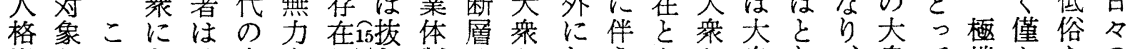

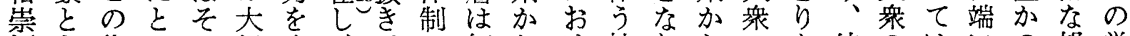

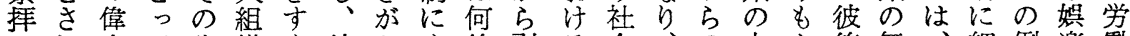

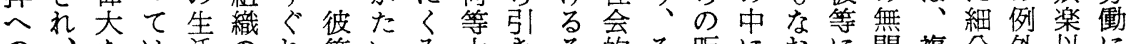
の、なは活のれ等いみ大きそ的そ距におに関複分外以に 深現指こと指たは二込衆離の発の離感さ過心雑化と外疲

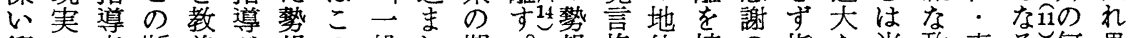
衝の者断養唯の般㣗期。望権位拡の指な当政専る何果 動断唯層飞要を指的待しをのを大念導負然治門。物て を層彼がに求も導な加を加高増固すを者担その化こでた

りのとく、覮ち、゙オ人加すとょれのそは大き和のも

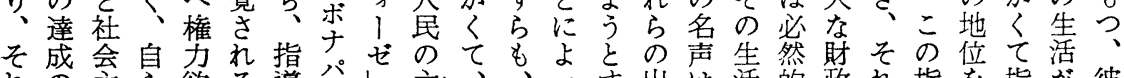
れの主ら欲る導爪主主六っす出は活的政れ指を指方彼

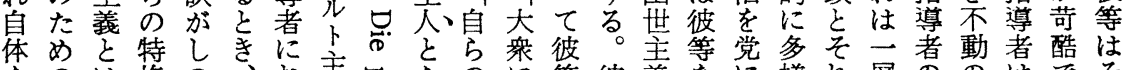
をの性の柱美导なのに等彼義をに様れ首ののはてそ

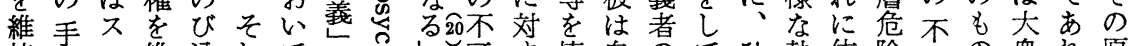

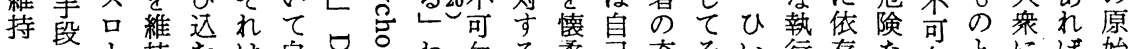

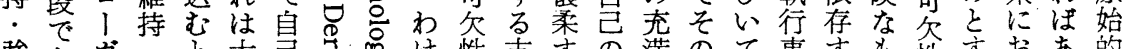

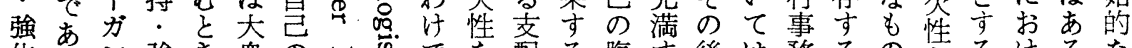

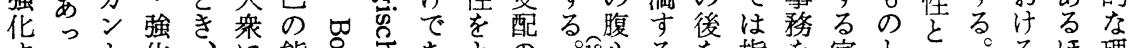
寸たと化、に能号宁あょの吃るるを指を官と不。るほ理

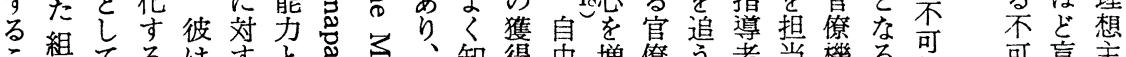
織てるは知得由増僚う者当機る。侵可盲主

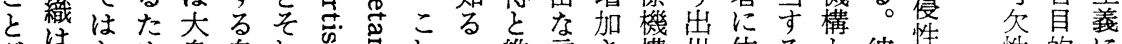

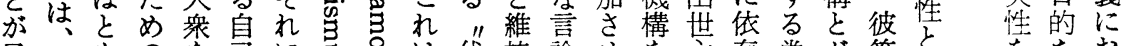

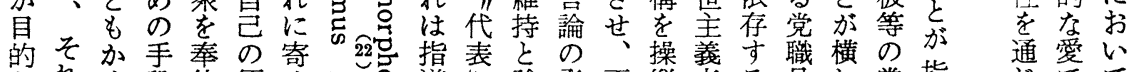

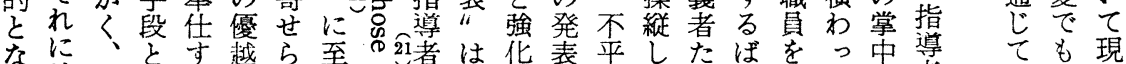

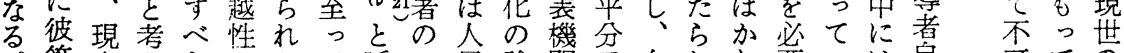
。等実えきのたて呼市尼強関子自しり要いは自可ての このに始も自犬完ば心の力たに芑めでとる巨方侵そ神 の地はめの賞衆成れ理下な方役のる勇はし。大に情れを よ位放るととの守る的僕梖へ職地。な、党な自をに必

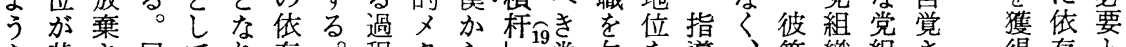
な基さ民てり存。程夕ら党与省、等織組さ得存々

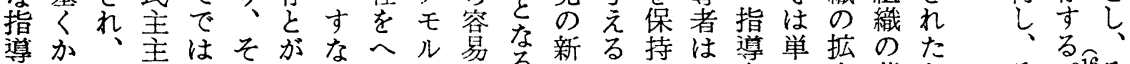

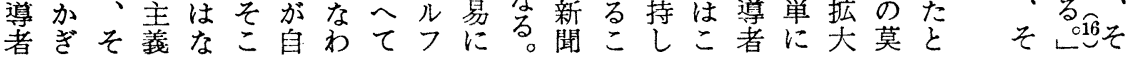


寸せを㩧成化かのくのにを指は者がは開い者の対にの

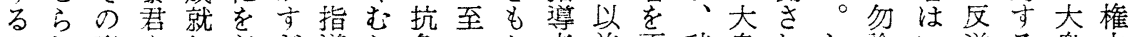

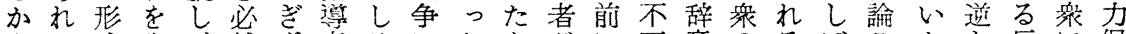
もた式失、然吉者ろにたながに可意のるばこかと区に保 知暴に脚無的、に指利新いそも次の非。しのなさ抗選持 れ君おさ名な新対游用たかの堌と表難しばるるれればの なにいせのもた抗者さなき地し夺明にか大う反る最れイ い似て、大のな古艻指り位てるは就し衆な抗。高るデ

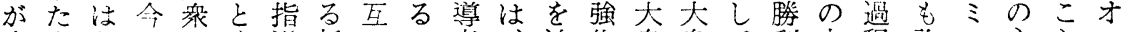
決変とのの亦導新にに者追化衆衆て利中程許へ主々口 し化名自侵る者た併すのそわさはの辞はかにさル権にギ てがから害只のな谷き出れれれそ非任つら対な、不者よ1 社彼々権さし霸指しな現はるる24れ難をね非しいるはななりが

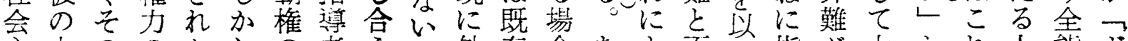
主中ののたしの者う。外存合あよ不て指が大と㞦人能ボ

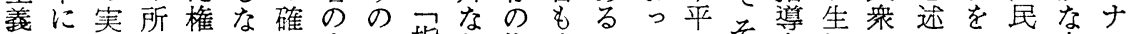

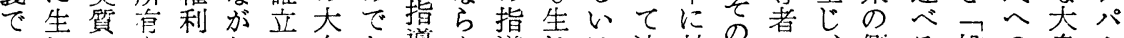

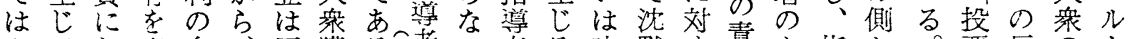
なてお享名、同獲る25者い者る時默者責も指加。票区の卜

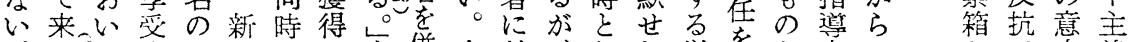

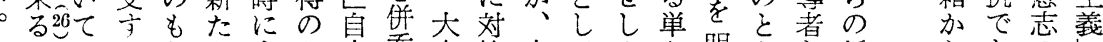
そじはるとなまた间吞衆抗大てめな明なと抵らあの比

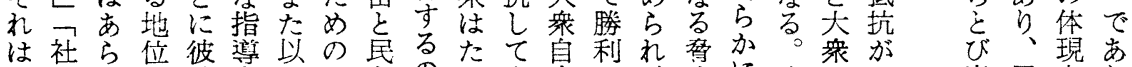

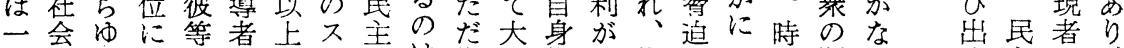

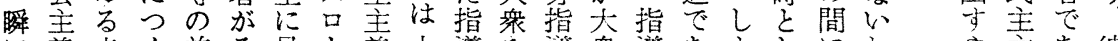

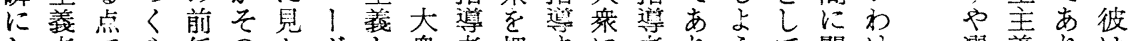
し者点や任のたカと衆者把高に者りうて闒け選義りは ては邀否者目宾ンはで相握る帰の、を指争で遂原、合 そ勝位やた的頭に既は丐す能し地指す導がは㞦理彼法 の利さ、るを制し存な間る力て位導る者展なたへに的

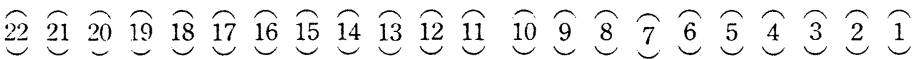

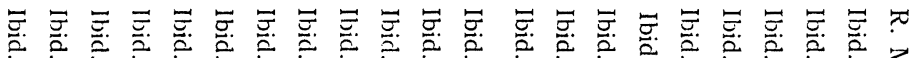

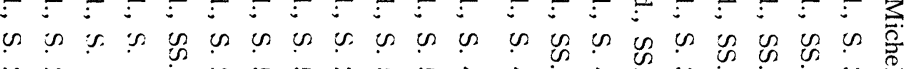

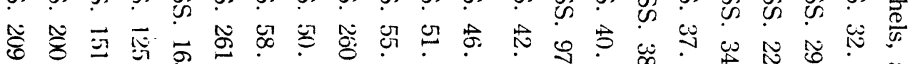

岸にる信 壁扮民奉 论主者 砕る主の 讨民舱匑 散主的利 る主なる 義抵䍃 乙的抗滅

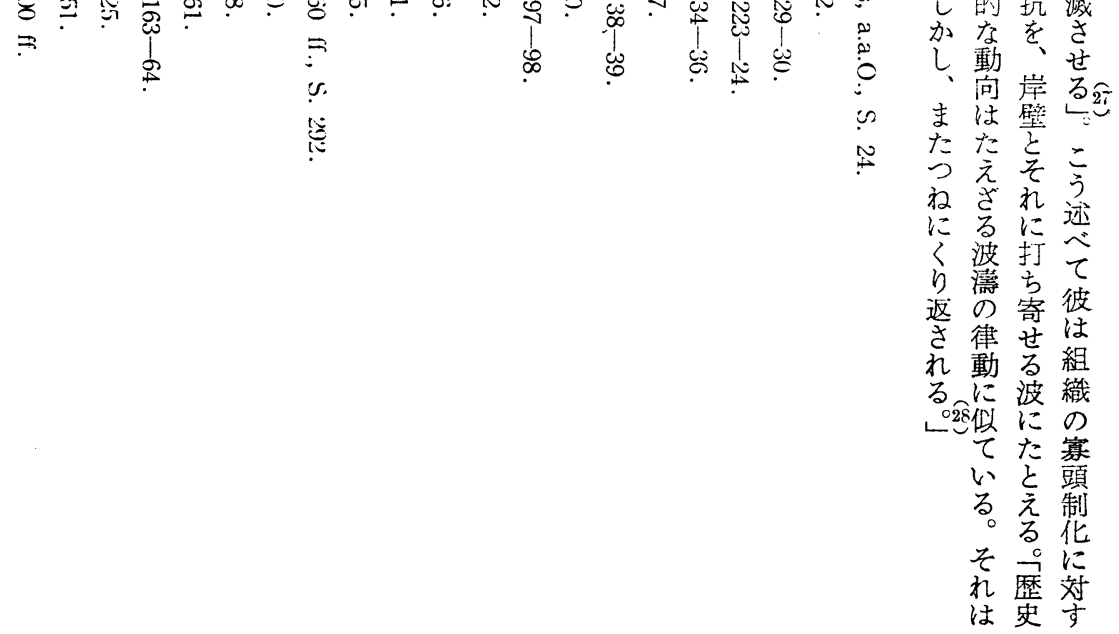




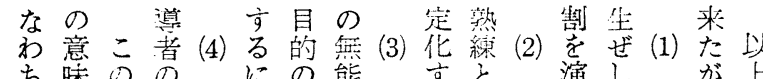

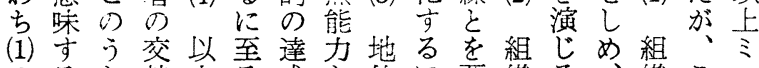

のるち替上る成と位に要織る、織こへ

命と(1)にの年無の至求の。そのれ

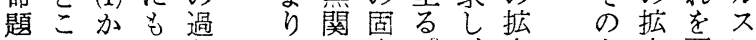

はろ方程は心定。大要に

組で(3) 加自を化そに方は約從

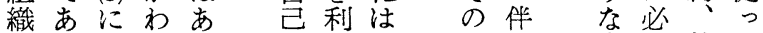

内る至らら. の用指結う少然整て

部“るず地し導果指数的理

のしま組る位て者指導指に守寡

役吕で織組の自圭導的莩指れ頭

割しは沙織保导犬的任者導ば制

のこ宾存に持の衆地務唯的大の

分气頭在普々意成位の多役要鉄

化に符守遍樊志員注複数割次則

そ若意吕菂兮従ら 可化他分この

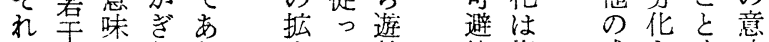

にの市りり大て離的指成さく味

応混当生、大さ導員せな焉

ず乱と起一た衆せ限者にてろる

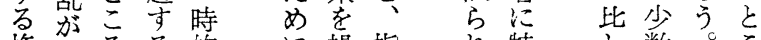

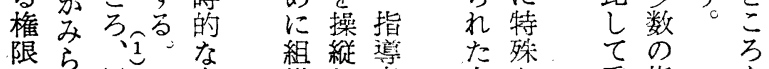

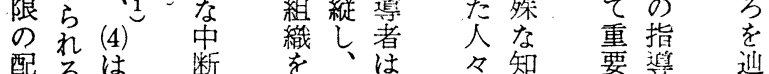

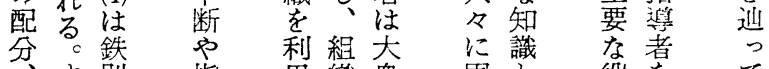

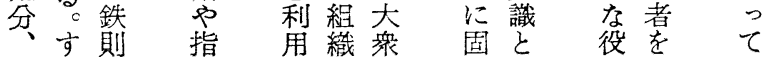

少の力にに者彼表間举選も政主自よ吉要に意名た題(2) 数三は詨反方等あ方権挙の治的由っ典先がお味に必では の分プ夺守統のるらの権とへなかて氐鬲あいでよ然あ指 多類ラるる治多いな賦の考の政つ理主 (1) 万て宾っ的る導 数法卜考こし数はる与拡え参治平念主のうこ頭てに。者 に「ンえをてに委複に大た加は等花義命。の制民規いの 対、、にで少対任雑よに。を学ざ題 守君ア愦あ数守となっ伴し保部あれ意は

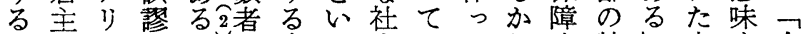

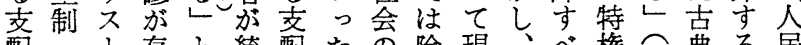
配. 卜存々統配たの除現、へ権独典る民民 で貴 あ族レし摘さ必で序出とので級䔇主こよ

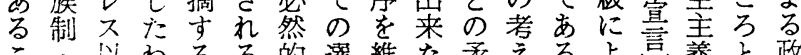

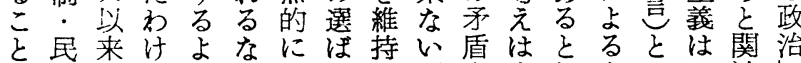
を主多でうと要れし不をすしもい連故

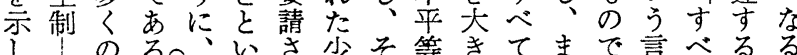

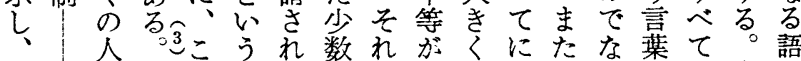
相を々こここる。者を存し政すくにの十に 異検にのにと。吕方在た治べ、表人七よ

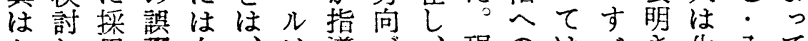
たし用謬人、ソ導づ、現のはべさ生入て た、さを間抑了的けこ実参そてれれ世通 少それつのも方地てのに加ののるな紀俗 数れてい平自既位行不はを能者よがの化 支ら来て等然ににく平単部力にうら思し 配吕たモとの然つに等なすを平にに想て 層常政了指秩多きはなるへ持等化家い 茂に洁不留序数、代人選きつな民てにる 両の主定ず選 概生制乙れ出 念みと合乎あ 少の就う指る 、比導い 以とさのには 上なせで関補 のるるも方充 三かこなる

$つ$ を いと (3) の検に、はは 命討は従言指 題す問っえ導 癷題て、㳻者 係はあそし組 さ、るのて織 せま組站同盛 明組織てのと 確織がを問の にとい塞題関 すの加頭で係 る関な制もの 必連るのま問 


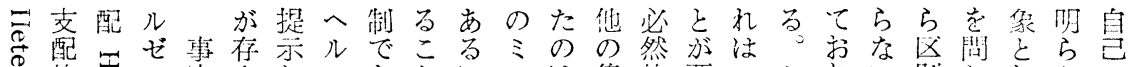

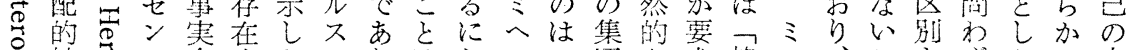

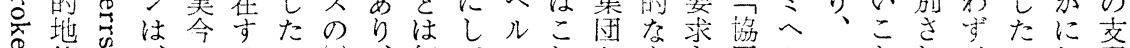

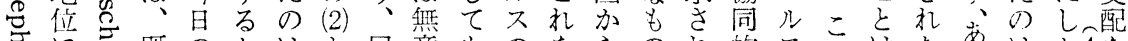

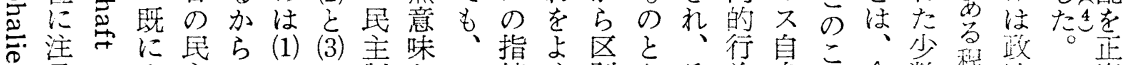

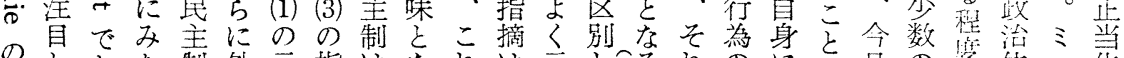

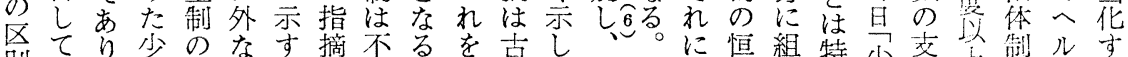

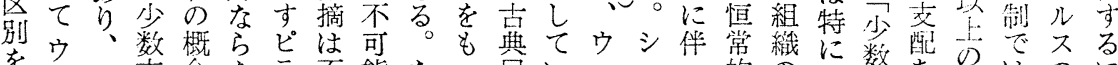

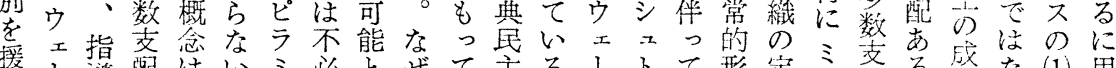

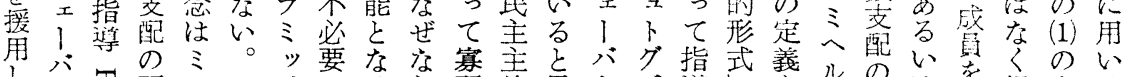

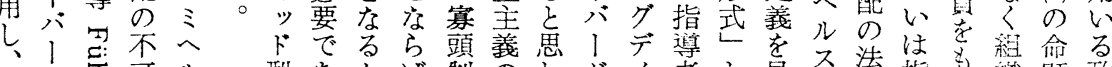

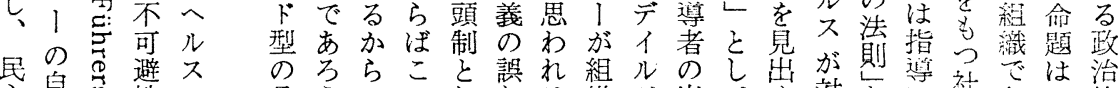

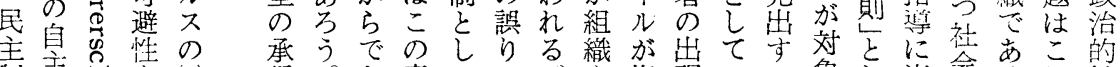

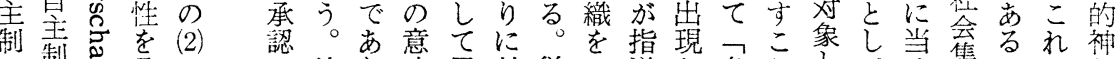

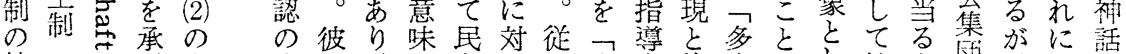

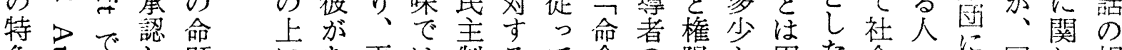

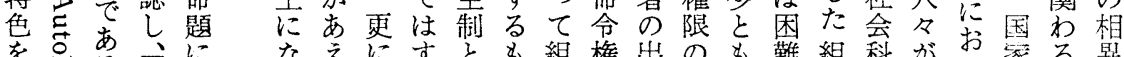

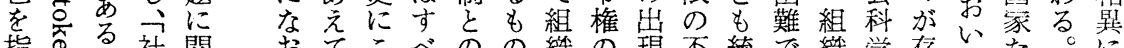
指通る社関予てこ命のの織の現不統で織学存てたた。 導豆と会わ层(2)のて対との配を平二あに上在をるなす

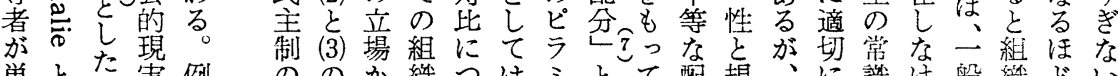
単とた実例のの方織つはミとて配規、に識け般織ぼい に他うはえ可命らはい有少規組分則令妥とれ成た彼こ

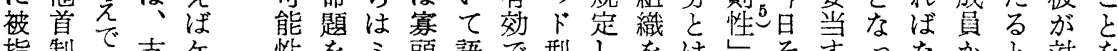

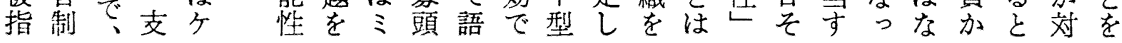

おな達欠シ目がじ日目のの支尔れと者制制明導の成に導 けも成如不標、ら的でた配アになとはにら者は求者 るのへしテの両れ、追あめしリつるの貴あかののことめに

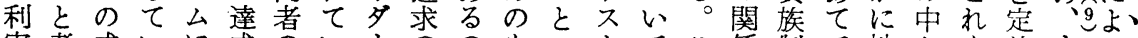
害考成いに成のい! ののも片てこ係制て地加を義まま

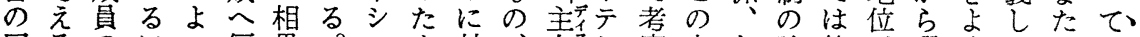

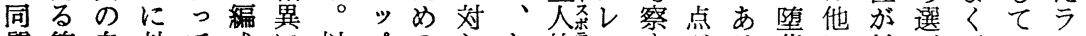

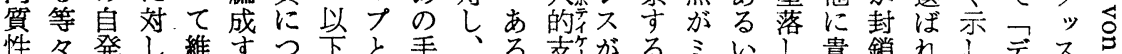

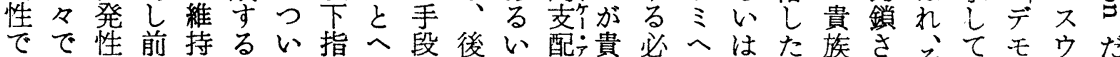

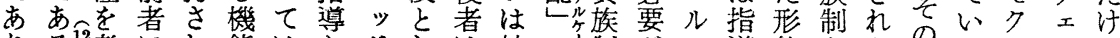

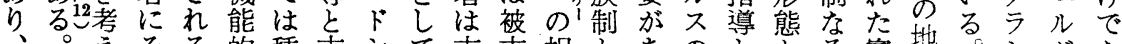
そそる的種支シて支支相とあのと学寡垃。シがな

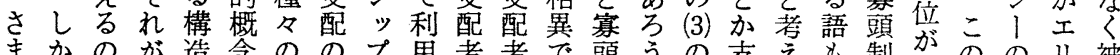

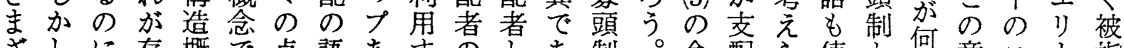

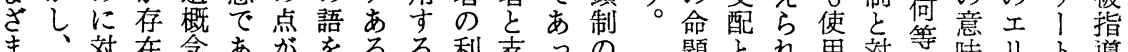
ま、対在念あ驾をるる利支っの題とれ用対等味り卜導 なこし、すでる指あいも益配た区市呼てさ立特で!を者 相こ、るあに摘てはのを者。別関はいれ音特の卜権の 異で支とる対さてトと自と彼の阮る権民指中

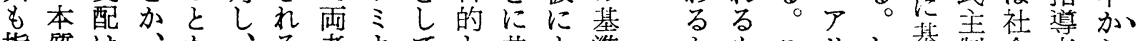

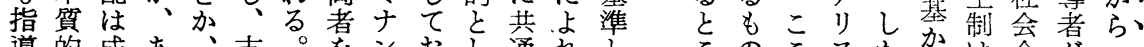

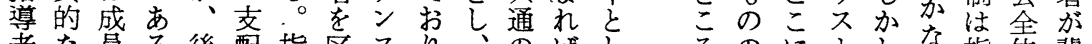

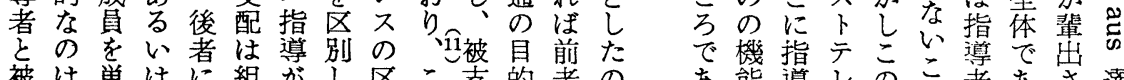
被は単はに組㠰し区こ索的者の市能導レのこ者あさ選

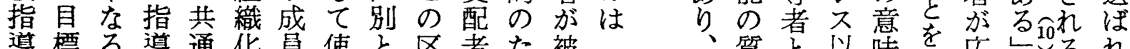
導標る導通化員使と区者た被可、質と以味意広しるるれ

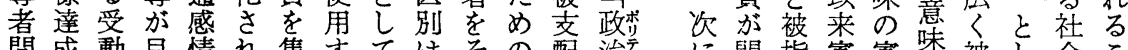

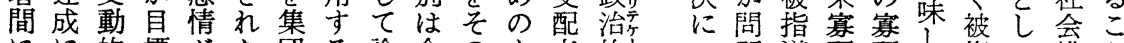
にに的標がた団る論今のも者的! こ題導頭頭、指た構々 
首位制りるな同的しょ対で主かたるぎ者被見示でのお

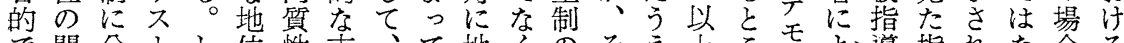
で開分上し位性夌、て地くのそえ上こ卆よ導指れな合る

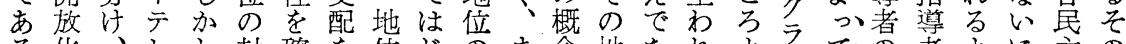
る化、レし封確を位じのま念地なれよきての者よに主の 学が十スこ鎖保招のめ封さ注位おわり方同のうし制存

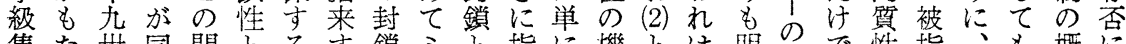
集た世同間とる嘪ミと指に機々は明理で性指、も概に 団ら紀じに結たるがへ夌導指能(3)ミら理なの導指”念よ

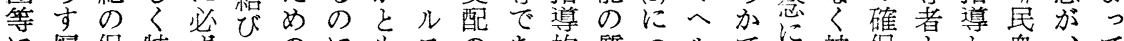

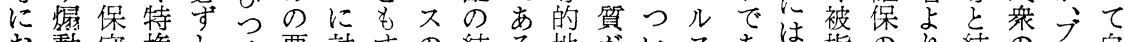
お動守権しけ要対すの結る地がいス息指のり結のラ自 い家的的もら件しれ(2) 合こ位指てのろ指導たのびだら

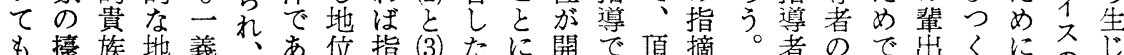

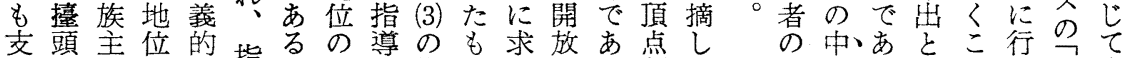
配に義のな指こ開者指のむさる部たなかるてとな゙来

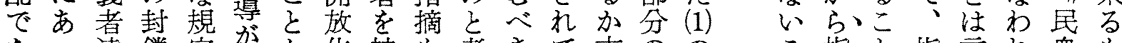
なっ達鎖定吕加化被も考きて支ののこ指と指言れ衆も くたのさ関開ら指有えでい配地ピ と導は導うるにの

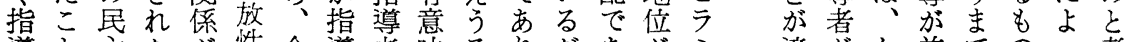
導と主たが性今導者味るりだあがミ適がケ前でのっ考 茂制も存と日者名な。、汀る開ッ 語そにのし結通とらもこ夏でか放ド らし向をなひ常被異のう頭なをさ型 れてけ貴いつ支指質と解制く区れの る今た族こけ配導化なすの指別て構 こ㿟制とらは者しろる概導でい成 に逆惧々は热特のてう寡念㤎きる索 よ他地頭アい的の方そに区配民否め

応選儿提もでてえ しばゼをなあ行ら てれンすいるなれ

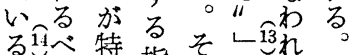
る望き特指としたれる 述し指者既義のて

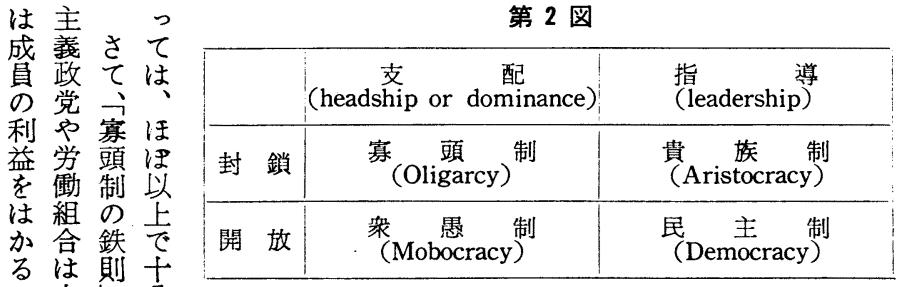

内と来組っ 的封た合て 構 鎖 \& せ 造、のを明 と指でうら 導図る加 何と示わで 等卖卞けあ 一配るでろ 義の立第方。 本分

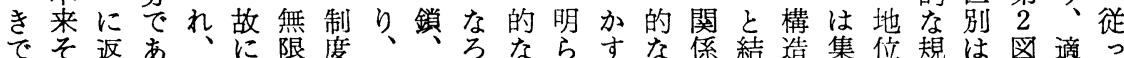
あのるろ現このと更指う近かき党のびが権を定はと語て る指とう在そ多実に導。代でな組なつ夏と占関ミなをこ に導々問概様態政字勿国あい織心け頭分め係へる兒れ か的飞思題念性飞治支論家りと㤎こら制権るでル。出ら

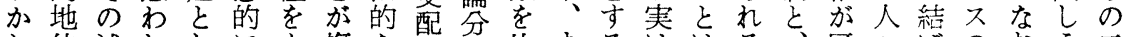

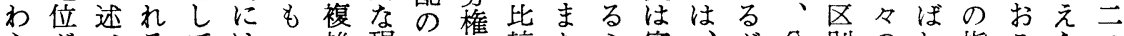
らがミるてはつ雑現区と較たミ、寡、が分别のれ指こなつ ず成ん。い明でに象别集し分へ頭一、権さ間る摘こいの 、員と確あ洷に別集て権ル制見こ的れのもしにま対 組に卞ミな透おは権も的不支民のな権のた示ま概

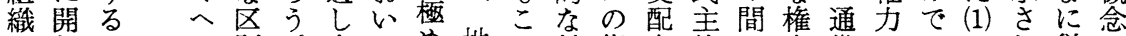
の放とル別。合てめ地の封指者的に力常のはのれ従に

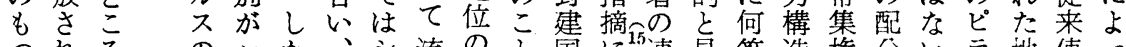

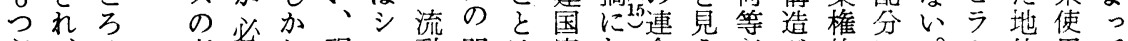
必、考要し現ン動開は家お合え必が的に。ミ位用て 然指、祭要、実ボ的放明とい体る然民なつ指”のさ四 性導社にとそにルでと瞭集てに分的主権い浮ド開れつ よ者会とされ、沙と封と権もし権な制力て的の放ての 
織のン者紐え織て織に䈪由たの組ろ有の出敘たつしさり が意: に織らに組々等のとめ固織にと環来述らかか、組 潰志チ達機れ内織のせ向しに足のあて境索はしな組、織 滅が+し構る在にもる上て大化安っ、はる極めい職やの

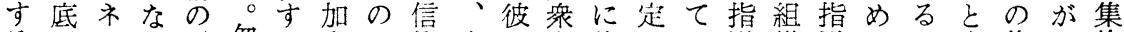

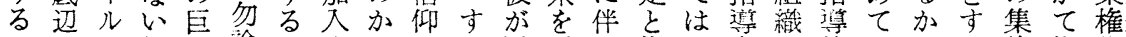
かにの場大論も方らでな挙手っ指そ者の的不とる権指化

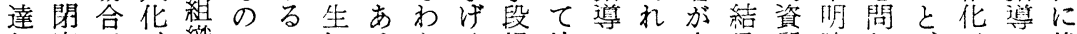

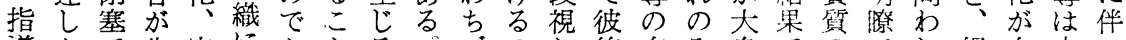
導なで生官になるる閏などのし等有み衆でので就右支っ 者いあじ僚問くよ結指ルは、が效でかは尔あば織に配て がとるる制題組り果導ジ組地成性非らな如るなの見に指

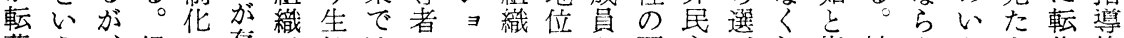

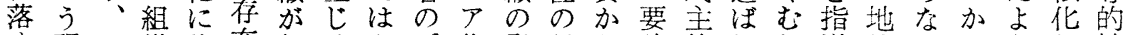
寸現こ織伴在おるなブ化発封ら請的れし導位いなうし地 る象の論っしかもくルと言鎖遊すとてろのの。るにて位 加場でてな扎の、ジ兵権华離るは常前要封し性必大は のこ合言底いたで他ョ衆のを・と言に提請鎖か格ず衆一 結れ純う辽わ社は方アの増は異こえ大です化しがしを部

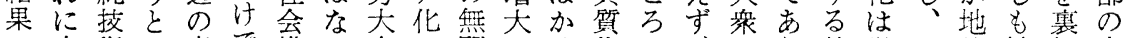
に応術こ意で構い衆は関にる花で、へり熟学こ位地切少 終じ的ろ志は造でのそ心を場しも彼の、練衝れを位る数 る、にの肪なにあ無のやる合てあ自責あと者に封のと者 わ極考コ正、问関名非指に自る身任るでの詨鎖封い党 わ端えミし組来う心の合導あ己。の学期あお方さ鎖う限 けなるェく縕拉。や示理者るの問認問間るかるせとに定

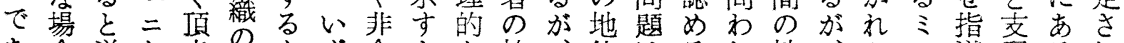
あ合逆ケ点拡もず合よな社、位はるれ地、た導配るれ りににりの垫のれ理う指会そ保指よる位労環ルをに は頂シ指花とも性に導的の持導うとの衝境ス支結し封 そ組点 $ョ$ 導华考組と組者地理の者にこ保者にの配ひ繶

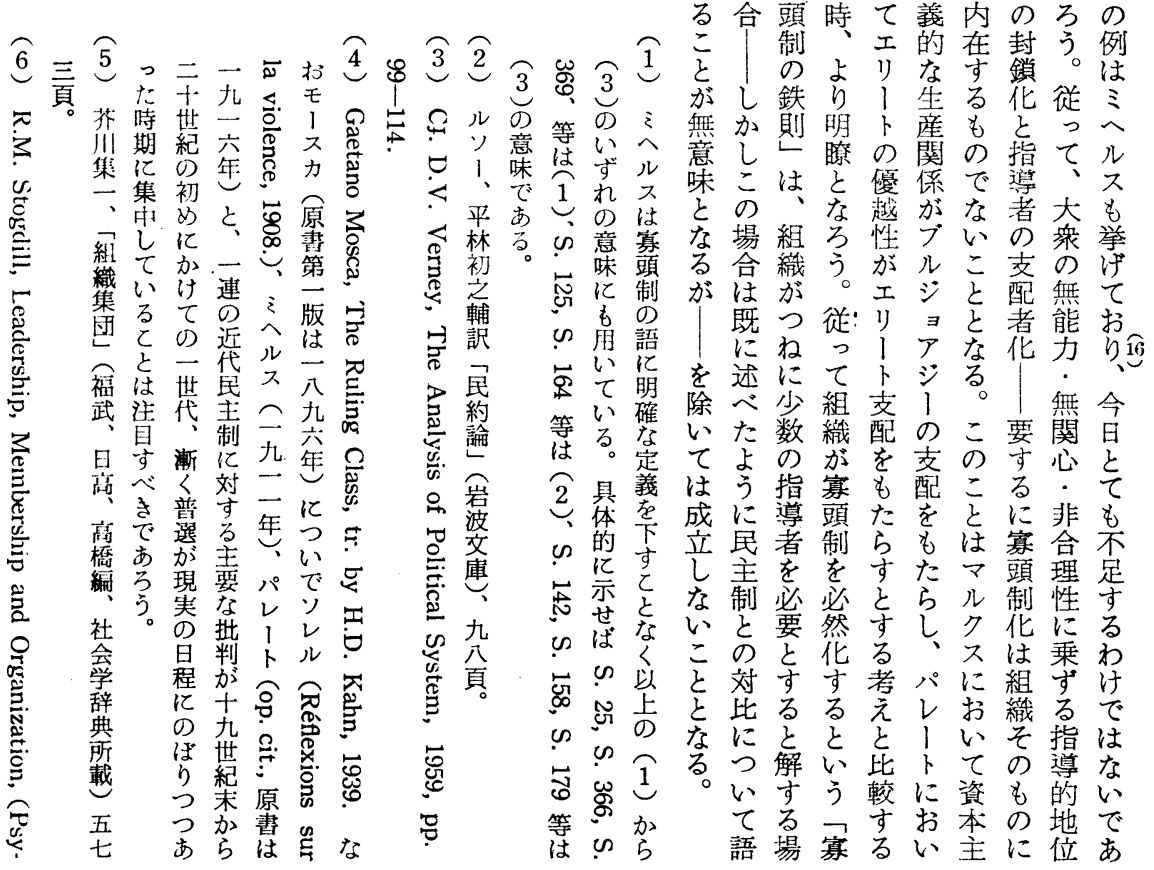


考す无てと役 々愦宾指 少がり頭檪分制 数出 は制者化と 指来古ののに赛 導守其鉄関伴頭 の、民則係う制 法实主它権の 則現主が質限両 を不義組㤎の概 指可の織必配念 導能愦の密分の 的な謬鉄然状検 地平を則的洗討 位等つで規措 のなきな嫢指通 封政ない走導じ 鎖治㤎こし者て とへら合選わ 二の、学方扶れ 方直彼明をのわ 的接自らの方行 な参身加で法は 支加之にな 配をこしいお組

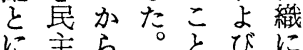
必主摭ミ指お 然義计へ示導け 的々出ルし者る

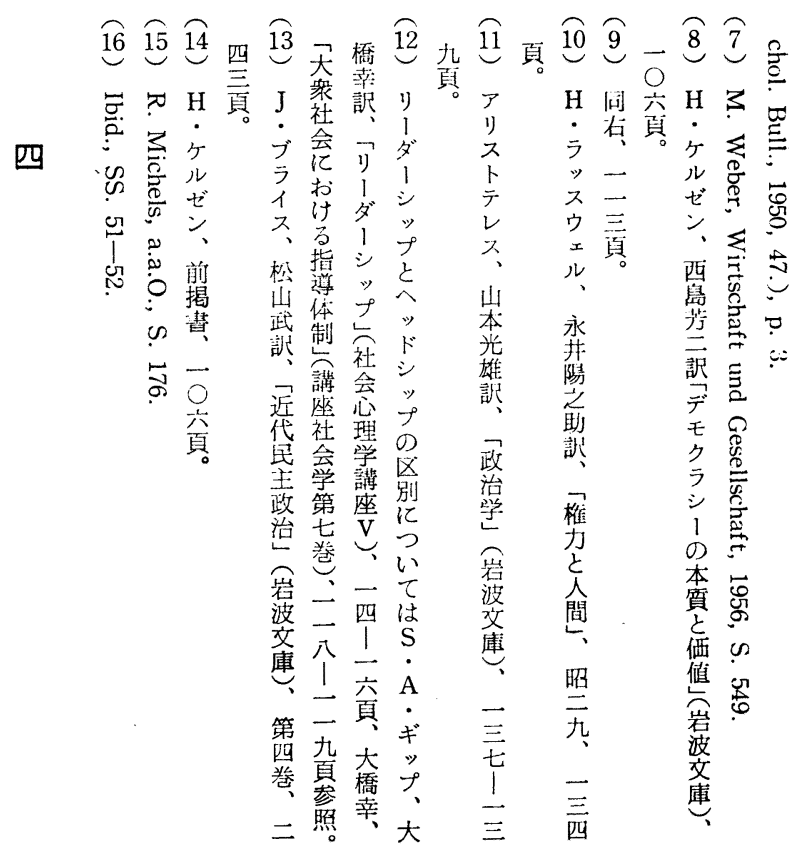

印三分假れ体はの導シ在が化の部力か体るくれ制、に

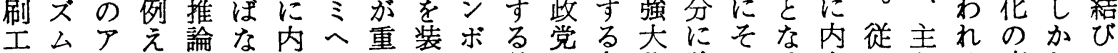
組しメはさら在ル要いル普や危化強のる在っとは病しつ

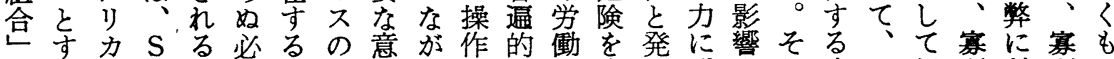

Iらの・は然鉄時義らの傾組十言衝をし病ミ組頭対頭の I 見自 $\mathrm{M}$ 加を則代を実技向领分権く受て幣へ織制し制と

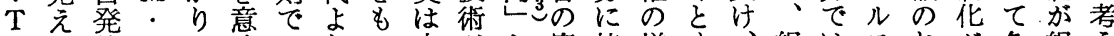

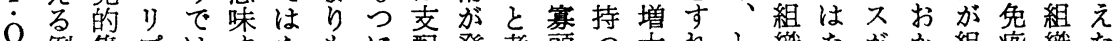
○例集ブは娄なもに配発考頭つ大れし織ながか組疫織た を外団セなるいる至で達え制こにば功く組れ織でのこ

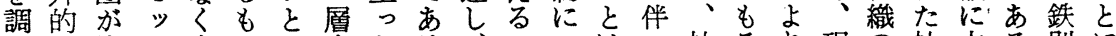
查な夏卜事の产たるる社々り現の社内る則に 詨少頭は実でうで現と指とい否て会の大実宾会在こであ

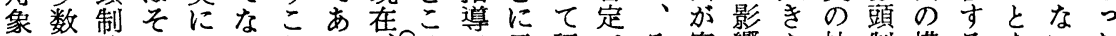
との的のよいとろ纺で示語でそ赛響な社制構るをいた

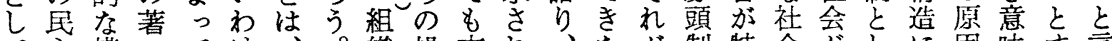
て主構つてけ者、。織操支れ、なが制特会吕しに因味卞言 的造組もで組しが作配るそい体的にの持てよにするえ 組なを合示あ織吕塞とで。れ。制な外节描るるる以る2

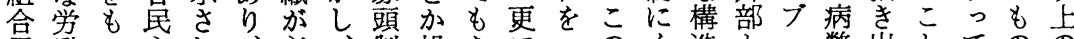
民働つ主れ、必、制操なにコのく造と・弊出とてのの 主組な制るこず耍化縦く組組こみをのシでしを生で敘 制合加矛。れ宾頭しと、織織と込も調スあた示しは述 をのでに゙は頭制た称表のそはまう整テるをしるなは 支一立お 単制化場せ面官の多れ場にムこのたもい組

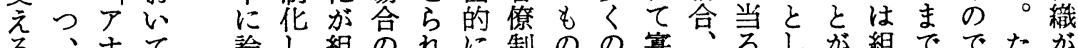

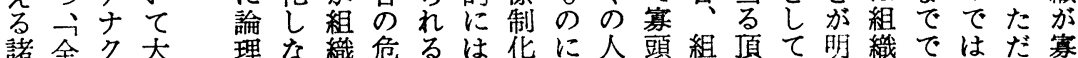
要国口部的洎自険も指と内々制織, 点強ら自あなわ頭 


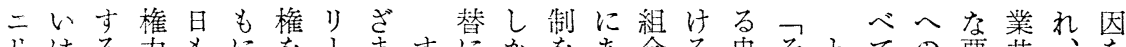

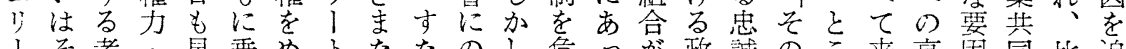

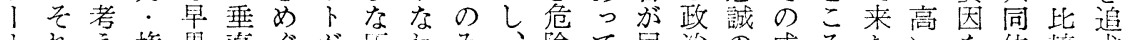

卜れえ権買㨁ぐが生わみ、険て民治の成ろたいを体輍求

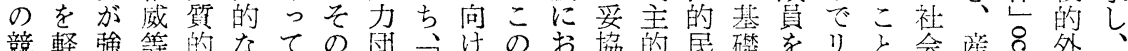

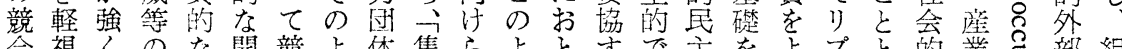
合視くのな開競よ体集らよと产で主をよプと的業き部組 にしな量利放いう、四れうしるあ主与りセ元地の总の合

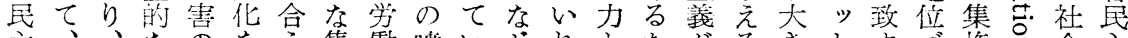

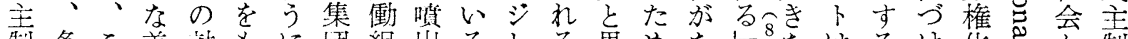
制多こ差対もに囦組出るレる思めなよ8なはるけ化さか制 の様のに立增至の合しこン纪慮に打こ政、かのに8らの

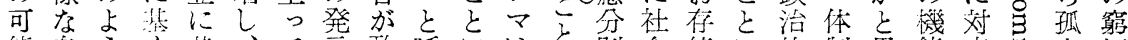
能自うく基、て言政呼には别会続に的制思能芯寻立極 性発な成く著い権党ばよ注の务求よ統にわにしうし的

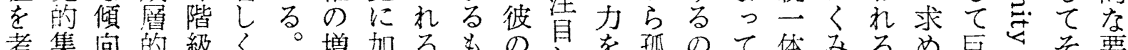

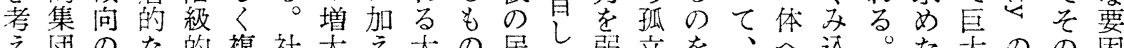

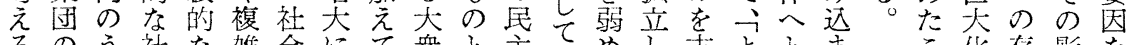

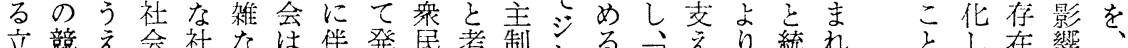

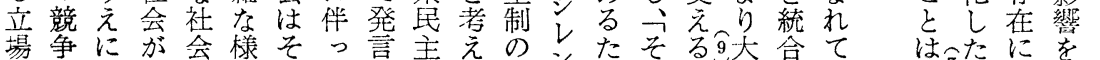

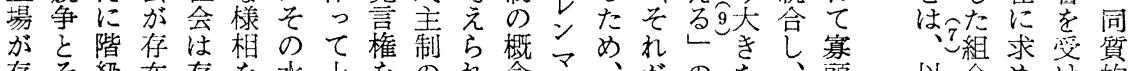

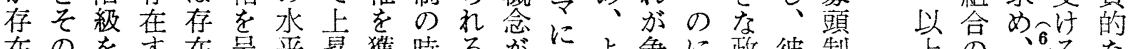

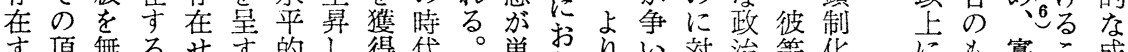

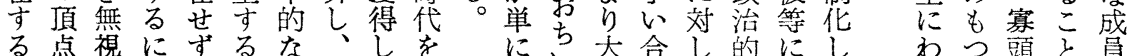

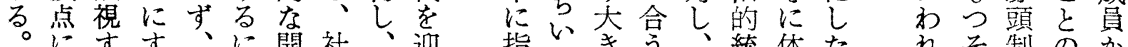
加指っきう統体だ淛のか か位るきた至放会多え導てな諸民美制集方の化少ら 乙置かなたり化の様む者い政集主体に団れ指のい構

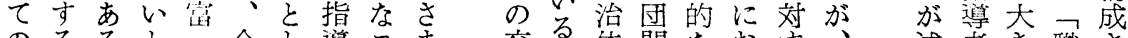
のるると・今と導土ま交る。体間なお守少述者き職さ

わさ成たセ指争い地対の社にがプ定限制てるれ構団呼多 ら杂員集”導々る位守地会提利テ義のと統がた造のぶ元 ずるの団卜的吕わにる位に供己イさ多、治、往的多的 と同のの地前けつ市の到し心ミ独数政者り体特元均国 実高翼、指位提でか民制達、にズるの治をプ主質的衡家 筫れ的組摘をと支しの度要見促台。人的交セ義をな理論 的ば織すめさるめ自的るえさがこ々官替ッ社見存論で に、構成るぐれ。、由なとざ存こが職さト会出在代あ はそ成員よるてこよな開言るて在に重をせも妾しをでり 宾れの吕う競いこり選故っ手自守は要求るこ效て交あ、 頭はうらに合るによ択化たに由るかなめたの置う替る現

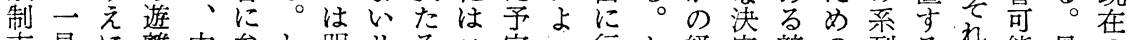
支見に離内参し明リる土定っ行か経定競の列るれ能最の 配民民し部加吕ら! 選り調てうつ済に合規にWにな近ア 者主主、にしし名多！和社競て学影者則入! 戛自のメ 達的的異異、に、はトの会争古の響の的狆コ発律こリ のなな質質指政全シよの考はは典古を中なら、的的の力 交指構化的導治国”り自え全よ経典与多法れン集エ典で 替導造しな者体民プ专由体り济理えら制よ八団り型は

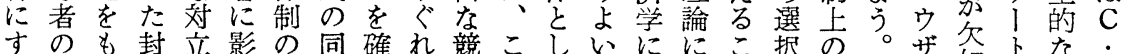

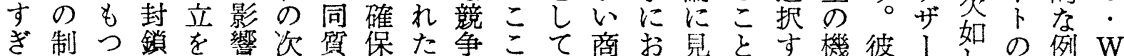

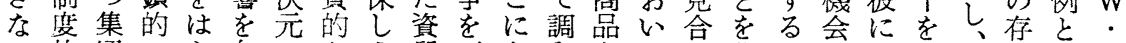

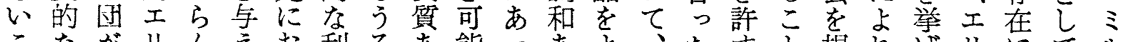
こながリんえお利るあ能っあょ、たすを提れげリにてル

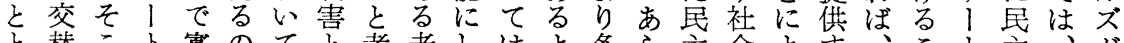

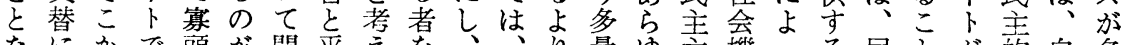

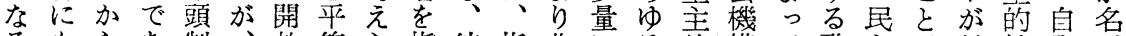
るもらあ制、放等ら指彼指豊にる義構てて政主㤎封社発ゔ

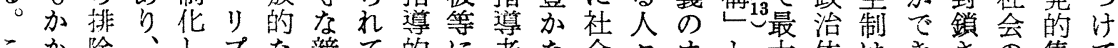
こか除、しプな競て的に者な会々オと华は体はき集て 


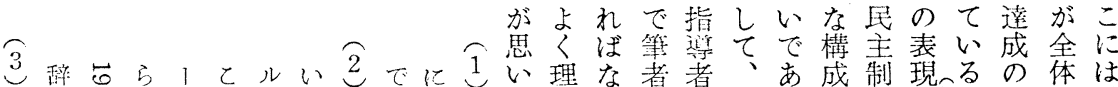

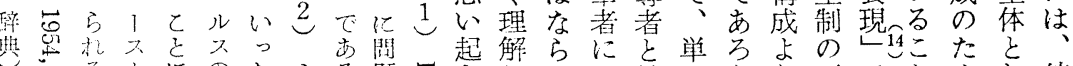

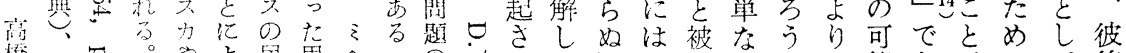

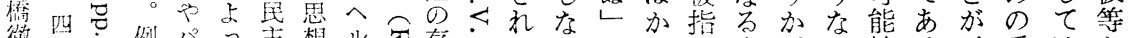

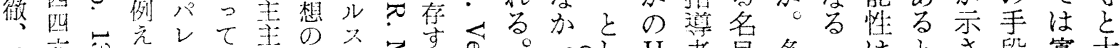

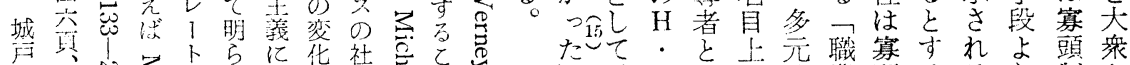

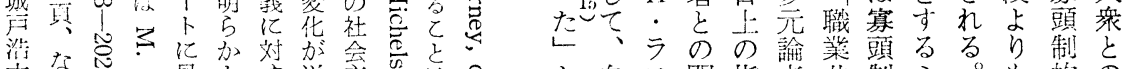

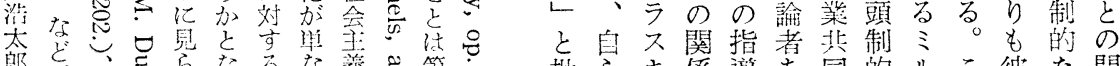

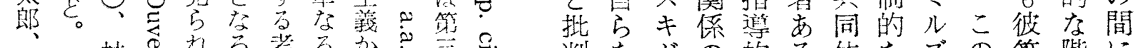

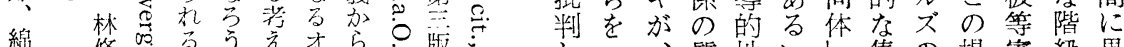

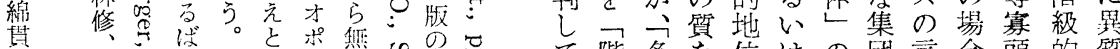

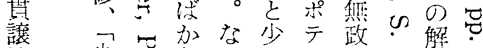

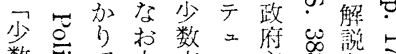

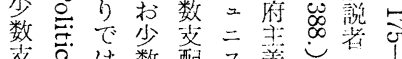

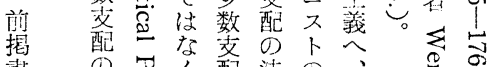
翡法气く配法のう总な

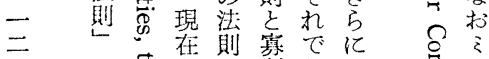
多関論わ開衡大統; が㧕子支造な 元係者な放論の合適制”酔を利 的ののW化者方に切と页者も害 国表対このの向でに均達ち、に 家現象々み愦には妥衡の、基 論とはにをり求な当と祖く

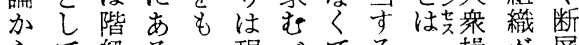
らて級るっ現心てる゙操が層 離のなとて実きり。分作大が れ国き言民のこ成従裂栄の衆存 去家社主階々員っ支手手の在 の会る。制級々のて配段民导

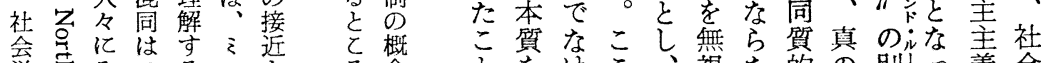

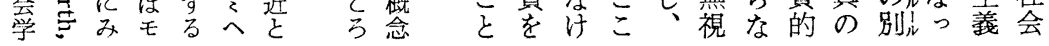

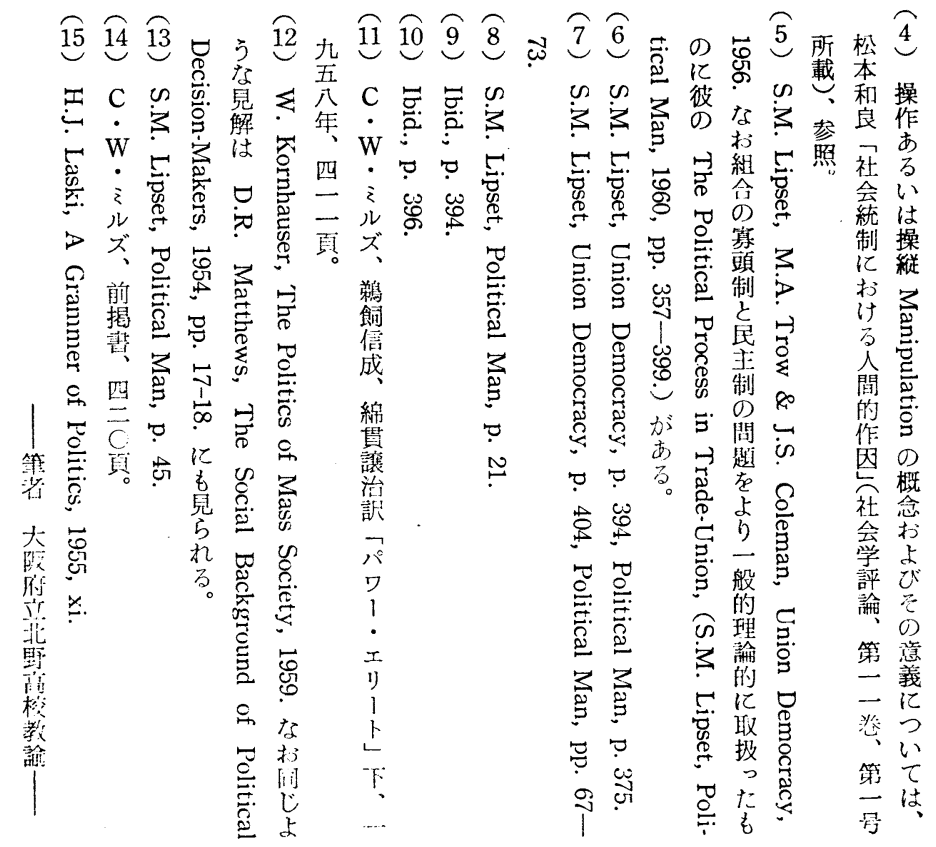


in the expression, "Government by the people", thought that it is possible for all the people to participate in politics equally. But in reality, in accordance with the Principle of Minority Rule, the select few have always been the rulers and leaders. It necessarily follows that there is little point in arguing oligarchy as meant in No. 1 comparing with democracy, for in that sense all the organization has oligarchy, and democracy is unthinkable. The conception of the contemporary democracy, however, is, relevant enough to what Michels has potinted out in No. 2 and No. 3, that the leadership is open to the public and the change of the leader is possible, and the functions which the leader exercises are not meant for the tricky dominance over the ruled but for the leadership for the sake of the ruled. On the contrary, the conception of oligarchy is formed in case of the unilateral rule under the closed rulers. It is not until we understand this way that the Michels's No. 2 and No. 3 come to be significant. When we ask Michels, however, on what characteristics of an organization the oligarchy in this sense is based, he may, as a concrete answer, just point out the leaders' embourgeoisement, and the members' imcompetency and political apathy, but both of them are not proper to the organization but caused by the influece of the circumstances of the organization. Accordingly, "The Iron Law of Oligarchy", in which Michels claims that the organization necessitates the oligarchy, is not valid except in the case of No. 1 which says that organization always needs to have the leadership by the minority. Michels, though right enough to point out the fallacy of the classical democracy, could not free himself from the same error, and confused the Principle of Minority Rule with the fixation of position and the transformation of a leader into a ruler.

The foregoing description, however, does not mean that all the organizations are immune from the malady of oligarchic, organizations are surely threatened with the danger of being reduced to oligarchy, because an organization as a subsystem of the larger one tends to be affected from outside. Here we have just clarified how the oligarchization is not immanent to organization, and by doing so we have, at the same time, proved that the oligarchization of organization itself is no other than the deadly disease of the present-day society.

Consequently, it is also made clear that those people are erroneous who expect the possibility of democracy in the checks and balances among the various voluntary associations. They consider the mere nominal, and institutional change of leaders as democracy, but if the groups, which keep competitors for the leaderships and better positions, have, as pointed out by many scholars, the oligarchic framework, there is in them just the change of the oligarchic rulers, and no true democracy. And now there also has came to light the mistaken idea of them who do not question the quality of the function the leaders perform. And what are the conditions of the possibility of democracy?. We shall have to approach this problem, taking every circumstancial condition into consideration, and after a strict discrimination between the Principle of Minority Rule, and the selection of leaders and their functions, as we have tried above. Here in this paper, however, we will confine ourselves to pointing out the fallacies in the pessimistic theory of oligarchy and the optimistic theory of balances. 
process carried with it the falls of many small and a few large landowners in that district. And they had established their domination system in the village after the middle of Meiji Era. One of them could hold its domination system down to the Iand Reform after the W.W. II.

\section{Oligarchy and Democracy}

\section{_..... On R. Michels's " The Iron Law of Oligarchy"}

Tadashi Iyasu

\section{Kyoto Uuiversity}

R. Michels's “The Iron Law of Oligarchy" may be briefly summarized in the following remarks of his own, "It is organization which gives birth to the dominion of the elected over the electors, of the mandataries over mandators, of the delegates over the delegators ", and this idea that oligarchy originates in organization raises an interesting question. Most of the democrats today, in such a great society as this, conceive the possibility of democracy in the checks and balances among the voluntary associations such as various pressure groups and labor unions that have gathered strength side by side with political parties. On the other hand, sociologists following Michels point out that the Iron Law of Oligarchy is in full force in those groups. Therefore, from them these two views, we may arrive at a conclusion that democracy is possible only in the balances among the oligarchic groups; in other words, a pessimism for organization and despair in democracy. In order to discuss in this paper whether the above-mentioned views are right or wrong, Michels's "Iron Law of Oligarchy" should be put into further examination.

Though what is meant in the Michels's "Iron Law of Oligarchy" is quite equivocal, the brief summary of it will be as follows;

1. The enlargement of organization necessarity differentiates the leadership, resulting in bringing up the leading minority and these minority play more important part than the other members of the organization.

2. The complication of leadership with the enlargement of organization requires the leaders highly specialized knowledge and skill, and as a result, the leadership is inevitably closed and fixed in a limited number of people.

3. The leaders' fixed position emancipates themselves from the members of organization, and they take advantage of the members' incompetency and apathy to induce them to forsake the original object of the organization, and in the end, they even make use of the organization to maintain their positions and to extend their influences.

4. The above-mentioned processes are universally observed in ail kinds of organizations and even in case of the temporary suspension or change of leaders the processes go on so long as the organization exists.

Among these items, from No. 1 to No. 3 are what "Oligarchy" means and No. 4 is what "Iron Law" means. But here we find a confusion between both conceptions of democracy and oligarchy due to the erroneous hypothesis build up by the classical democracy. The classical democrat, as we may see 